\title{
Protective effects of different doses of inhaled fenoterol on methacholine-induced bronchoconstriction in asthmatic children
}

\author{
Division of Allergy, Clinical Immunology and Rheumatology Department of Pediatrics \\ Universidade Federal de São Paulo - Escola Paulista de Medicina, São Paulo, Brazil
}

\begin{abstract}
Objective: To evaluate the protective effect of different doses of inhaled fenoterol $(F)$ on bronchoconstriction induced by methacholine (M). Design: randomized double-blind study. Setting: Referrence center. Participants: 9 children (aged from 7 to 15 years old), with mild or moderate asthma and allergic to $D$. pteronyssinus. Intervention: On the first day, the $M$ concentration necessary to induce a $20 \%$ fall in the forced expiratory volume in the first second $\left(F E V_{1} ; P_{20} F_{F V}\right)$ was determined using closed circuit inhalation (De Vilbiss 646). On subsequent days, the children inhaled a dose of $F$ ( 25 or 50 or 100 or $200 \mathrm{mg}$ ) through the same circuit and, after 15 minutes the $\mathrm{FEV}_{1}$ was measured, becoming the basal value. Bronchoprovocation was then initiated using the concentration prior to the $\mathrm{PC}_{20} \mathrm{FEV}_{1}$ of the first day and continuing until there was a $20 \%$ fall in the $\mathrm{FEV}_{1}$. This concentration was the "new" $\mathrm{PC}_{20} \mathrm{FEV}_{1}$. Results: $\mathrm{F}$ in a dose of $25 \mathrm{mg}$ protected 2 of the 9 children, in a dose of $50 \mathrm{mg}$ protected 4 of the 9 and in doses of 100 and $200 \mathrm{mg}$ protected all children. We did not observe any relationship between the magnitude of the bronchodilation and bronchoprotection induced by the inhalation of F. Conclusions: Our results suggest that a dose of $100 \mathrm{mg}$ of $\mathrm{F}$ is capable of inducing bronchoprotection in children with mild/moderate asthma.
\end{abstract}

Uniterms: Asthma. Children. Bronchial hyperreactivity. Beta agonists. Fenoterol. Methacholine.

\section{INTRODUCTION}

I nhaled short-acting beta 2 agonists constitute the first choice medication for the treatment of acute asthma flares and in preventing bronchospasms induced by exercise. ${ }^{1-5}$ One of the most widely used in Brazil is fenoterol in solution form for nebulization. It is

\footnotetext{
Address for correspondence: Dirceu Solé

Av. Paes de Barros, 844 ap. 61

São Paulo/SP - Brasil - 03114-000
}

also available as a metered dose inhaler (MDI) in doses of 100 and $200 \mathrm{mg} /$ puff. Previous studies have tried to relate its use to the increase in asthma mortality, which we did not observe in a previous study ${ }^{6}$ and was not confirmed by a meta-analysis study. ${ }^{7}$

Previous studies have shown that fenoterol is capable of blocking the bronchospasm induced by the inhalation of histamine ${ }^{8-12}$ and methacholine $e^{8,9}$ and also protect against exercise-induced asthma (EIA). ${ }^{13}$ A $50 \mathrm{mg}$ dose was enough to avoid EIA ${ }^{13}$ and $10 \mathrm{mg}$ avoided brochoconstriction caused by inhaled histamine. ${ }^{12}$

In this study we evaluate the capacity of inhaled fenoterol for the protection of methacholine-induced bronchospasm in Brazilian atopic asthmatic children. 
METHODS

Nine children, from 7 to 15 years of age (6 boys), with mild or moderate atopic asthma, ${ }^{1}$ took part in this study. The atopic status was characterized by a positive skin prick test to Dermatophagoides pteronyssinus. All the children were able to perform espirometric measurements in an appropriate manner. ${ }^{14}$ This study was approved by the UNIFESP-EPM Ethical Committee and the children were enrolled after their parents gave informed consent.

The patients were submitted to bronchoprovocation (BPT) with methacholine according to the method standardized in our Division by Mallozi et al., ${ }^{15}$ and modified from Chai et al. ${ }^{16}$ Upon being included in the study, the exclusion intervals of the following drugs were observed: short-acting beta 2 agonists and aminophylline, 8 hours; ipratropium bromide, 12 hours; slow-releasing theophylline, 24 hours; classic antihistamines, 7 days; nonclassic antihistamines, 15 days; disodium chromoglycate, 15 days; oral and inhaled corticosteroids, 30 days.

Five BPT's were carried out, always in the morning, interspersed with a day of rest. All patients were asymptomatic and $\mathrm{FEV}_{1}$ was greater than or equal to $80 \%$ of the predicted normal values. ${ }^{17}$

At the first $\mathrm{BPT}$ the methacholine $\mathrm{PC}_{20} \mathrm{FEV}_{1}$ (concentration of methacholine capable of inducing a $20 \%$ fall in the FEV , baseline value) was established. For this BPT, the methacholine was inhaled in increasing concentrations $(0.025 ; 0.25 ; 1.0 ; 2.5 ; 10.0$ and $25.0 \mathrm{mg} / \mathrm{mL}$ ) until a fall in the $\mathrm{FEV}_{1}$ took place, greater or equal to $20 \%$ of the baseline value. The methacholine $\mathrm{PC}_{20} \mathrm{FEV}_{1}$ calculation was extrapolated using monolog graph paper.
On subsequent days the patients inhaled fenoterol 15 minutes before the BPT was carried out. The fenoterol was administered using the same inhalation closed circuit (De Vilbiss 646) and $0_{2}(5 \mathrm{~L} / \mathrm{min})$ in different concentrations each day, distributed using the randomized double-blind method ( $25 \mathrm{mg}, 50 \mathrm{mg}, 100 \mathrm{mg}$ and $200 \mathrm{mg}$ ).

The BPT's were started after the child had inhaled saline solution to obtain the baseline $\mathrm{FEV}_{1}$. Fenoterol was then inhaled and 15 minutes later, another $\mathrm{FEV}_{1}$ was obtained which became the basal value for the remainder of the test. The BPT began with the inhalation of the previous concentration of methacholine necessary to obtain the initial $\mathrm{PC}_{20} \mathrm{FEV}_{1}$, followed by larger doses until the $20 \%$ fall in the $\mathrm{FEV}_{1}$ was obtained, establishing a new methacholine $\mathrm{PC}_{20} \mathrm{FEV}_{1}$ for each dose of inhaled fenoterol. The $\mathrm{PC}_{20} \mathrm{FEV}_{1}$ with values in excess of $38.78 \mathrm{mg} / \mathrm{mL}$ were considered to be equal to $40.0 \mathrm{mg} / \mathrm{mL}$.

The methacholine $\mathrm{PC}_{20} \mathrm{FEV}_{1}$ were expressed in $\mathrm{mg} / \mathrm{mL}$ for each inhaled fenoterol concentration and in relation to the value obtained during the first provocation, by simple division. To analyse the results, non-parametric tests were used (Friedman, Fisher) considering the null hypothesis rejection level at $5 \%$.

\section{RESULTS}

All the children underwent the BPT without presenting any adverse effects. The initial $\mathrm{PC}_{20} \mathrm{FEV}_{1}$ of all of them was equal to or less than $8 \mathrm{mg} / \mathrm{mL}$. The analysis of the various $\mathrm{PC}_{20} \mathrm{FEV}_{1}$ observations showed values significantly higher than baseline after inhalation of 100 and $200 \mathrm{mg}$ of fenoterol (Table 1).

Table 1

$\mathrm{PC}_{20} \mathrm{FEV}_{1}$ methacholine values after inhalation of different doses of fenoterol.

\begin{tabular}{cccccc}
\hline Child & $\begin{array}{c}\text { Baseline } \\
(\mathbf{a})\end{array}$ & $\begin{array}{c}\mathbf{2 5} \mathbf{~} \mathbf{g} \\
\mathbf{( b )}\end{array}$ & $\begin{array}{c}\mathbf{5 0} \mathbf{~} \mathbf{g} \\
\mathbf{( c )}\end{array}$ & $\begin{array}{c}\mathbf{1 0 0} \mathbf{~} \mathbf{g} \\
\mathbf{( d )}\end{array}$ & $\begin{array}{c}\mathbf{2 0 0} \mathbf{~ m g} \\
(\mathbf{e})\end{array}$ \\
\hline 1 & 3.27 & 3.55 & 19.50 & 7.30 & 7.30 \\
2 & 0.10 & 0.008 & 0.09 & 0.36 & 0.35 \\
3 & 0.0215 & 0.68 & 0.63 & 1.55 & 5.70 \\
4 & 3.77 & 3.77 & 4.45 & 16.00 & $>38.40$ \\
5 & 6.75 & 14.45 & 15.45 & 36.50 & $>38.78$ \\
6 & 5.90 & 5.60 & 9.20 & $>38.78$ & $>38.78$ \\
7 & 8.00 & 10.00 & 15.00 & $>38.78$ & 5.00 \\
8 & 0.36 & 0.13 & 1.275 & 3.20 & 6.40 \\
9 & 1.85 & 0.42 & 1.30 & 6.00 & 18.13 \\
\hline Mean & 3.36 & 4.29 & 7.43 & 16.77 & \\
\hline
\end{tabular}

Friedman: $\mathrm{H}$ calculated $=27.727^{*}$

Dunn: $a, b<d, e$ 
Table 2

Ratio between the $\mathrm{PC}_{20} \mathrm{FEV}_{1}$ methacholine before and after inhalation of different doses of fenoterol.

\begin{tabular}{ccccc}
\hline Child & $\begin{array}{c}\mathbf{2 5} \mathbf{~ m g} \\
\text { (b) }\end{array}$ & $\begin{array}{c}\mathbf{5 0} \mathbf{~} \mathbf{g} \\
\text { (c) }\end{array}$ & $\begin{array}{c}\mathbf{1 0 0} \mathbf{~} \mathbf{g} \\
\text { (d) }\end{array}$ & $\begin{array}{c}\mathbf{2 0 0} \mathbf{~ m g} \\
\text { (e) }\end{array}$ \\
\hline 1 & 1.08 & 5.96 & 2.23 & 2.23 \\
2 & 0.08 & 0.90 & 3.60 & 3.50 \\
3 & 31.60 & 29.30 & 72.00 & 265.10 \\
4 & 1.00 & 1.18 & 4.20 & 4.88 \\
5 & 2.14 & 2.29 & 5.40 & 5.90 \\
6 & 0.95 & 1.60 & 6.78 & 6.80 \\
7 & 1.23 & 1.90 & 5.00 & 5.00 \\
8 & 0.36 & 3.54 & 8.90 & 3.89 \\
9 & 0.22 & 0.70 & 3.24 & 3.46 \\
\hline Mean 4.30 & 5.26 & 12.37 & 34.53 &
\end{tabular}

Dunn: $b<d$, e $c>e$

The ratio between the two $\mathrm{PC}_{20} \mathrm{FEV}_{1}$ values, obtained before and after protection using the four inhaled doses is shown in Table 2. Considering a ratio of at least 2 (doubling dose) as a positive value, the mean ratio after inhalation of $25 \mathrm{mg}$ of fenoterol was 4.3. However, only 2 patients were in fact protected. The same result was observed with the $50 \mathrm{mg}$ dose; in this case 4 of the 9 patients were protected $(\mathrm{p}=0.3147)$. With the 100 and $200 \mathrm{mg}$ concentrations all the patients were protected.

The response to the inhalation of different doses of fenoterol showed, after 15 minutes, a similar increase (9 to $12 \%$ ) in the $\mathrm{FEV}_{1}$ values, with no significant differences.

\section{DISCUSSION}

Short-acting beta 2 agonists, because of their bronchodilating effect, are widely used in treating acute exacerbations of asthma and in the prevention of EIA.

The continuous use of these agents has been associated with a deterioration in the control of asthma and with mortality. ${ }^{18,19}$ The main causes for these possible effects have not been clarified yet and are still unknown, but have been related to inhaled drugs, especially via metered dose inhaler. ${ }^{20}$

\section{REFERENCES}

1. Sociedade Brasileira de Alergia e Imunopatologia, Sociedade Brasileira de Pediatria, Sociedade Brasileira de Pneumologia e Tisiologia. $1^{\circ}$ Consenso Brasileiro no Manejo da Asma, São Paulo: Bg Cultural;1994:42.
Worsening of asthma was not proved in recent studies. ${ }^{21,22}$ These studies showed that the regular use of inhaled short-acting beta 2 agonists cause neither harmful nor beneficial effects in the control of asthmatic patients. Thus, the recommendation is that these drugs be used only when necessary, although when an individual patient has better control of the asthma with continuous use, this treatment should not be discarded. ${ }^{21}$

Several asthma management guidelines ${ }^{1-5}$ recommend the use of beta 2 agonists only as needed (for acute episodes). Larger doses than recommended for inhaled beta 2 agonists are not necessary for obtaining the same bronchodilation: the occasional side effects are doserelated. ${ }^{1-5}$

Our study shows that there may be a protective bronchodilating effect using much smaller doses of fenoterol, such as 25 and $50 \mathrm{mg}$, but which do not protect all patients. This fact was observed with a minimum protective dose of $100 \mathrm{mg}$ which, for individual patients, can be evaluated using 25 and $50 \mathrm{mg}$ doses.

Although we evaluated the protective dose of fenoterol needed to protect against methacholine-induced bronchospasm, it seems reasonable to recommend the dose of $100 \mathrm{mg}$ of fenoterol as the initial dose for treatment of an acute attack of asthma.

2. Global Strategy for asthma management and prevention. NHLBI/WHO Workshop. National Heart, Lung and Blood Institute publication 1995;95:3659.

3. Spector SL, Nicklas RA. Practice parameters for the diagnosis and treatment of asthma. J Allergy Clin Immunol 1995;96:707-870.

4. Canadian Thoracic Society, Canadian Paediatric Society, Canadian Society of Allergy and Immunology, Canadian 
Association of Emergency Physicians, College of Family Physicians of Canada, and Family Physician Asthma Group of Canada. Report on the working groups for the Canadian Asthma Consensus Conference. Can Respir J 1996;3:1B- 44B.

5. National Institutes of Health and National Heart, Lung and Blood Institute. Practical Guide for the Diagnosis and Management of Asthma, NIH publication 1997;97:4053.

6. Naspitz CK, Solé D, Salto-Jr JJ. Beta 2 agonists and death from asthma. J Allergy Clin Immunol 1994;93:677.

7. Mullen M, Mullen B, Carey M. The association between b-agonist use and death from asthma. A meta-analytic integration of case-control studies. JAMA 1993;270:1842-5.

8. Bandouvakis J, Cartier A, Roberts R. The effect of ipratropium bromide and fenoterol on methacholine- and histamine-induced bronchoconstriction. Br J Dis Chest 1981;75:295-305.

9. Salome CM, Schoeffel RE, Woolcock AJ. Effect of aerosol and oral fenoterol on histamine and methacholine challenge in asthmatic subjects. Thorax 1981;36:580-4.

10. Salome CM, Schoeffel RE, Yan K, Woolcock AJ. Effect of aerosol fenoterol on the severity of bronchial hyperreactivity in patients with asthma. Thorax 1983;38:854-8.

11. Salome CM, Wright W, Sedgwick CJ, Woolcock AJ. Acute effects of fenoterol (Berotec) and ipratropium bromide (Atrovent) alone and in combination on bronchial hyperresponsiveness in asthmatic subjects In: Black $\mathrm{J}$, Armour C, editors. Mechanisms in Asthma Pharmacology, Physiology, and Management. New York: Alan R Liss 1988;405-19.

12. Magnussen H, Rabe KF. Low dose fenoterol aerosol protects against histamine-induced bronchoconstriction in mild asthmatics: a dose response study. Clin Exper Allergy 1992;22:690-3.

13. Rabe KF, Jörres R, Magnussen $H$. The effect of 10, 50 and $200 \mathrm{mg}$ inhaled fenoterol on exercise induced asthma. Clin Exper Allergy 1993;23:440-5.

14. American Thoracic Society. Lung function testing selection of reference values and interpretative strategies. Am Rev Respir Dis 1991;144:1202-18.

15. Mallozi MC, Solé D, Naspitz CK . Broncoprovocação com histamina e metacolina em crianças com asma brônquica e crianças normais. J Pneumol 1991;17:69-73.

16. Chai H, Fan RS, Froehlich LA. Standardization of bronchial inhalation challenge procedures. J Allergy Clin Immunol 1975;56:323-7.

17. Polgar G, Promadaht V. Pulmonary function testing in children. Philadelphia: WB Saunders 1971;273.

18. Spitzer WO, Suissa S, Ernst P, et al. The use of b-agonists and the risk of death and near death from asthma. N Engl J Med 1992;326:501-6.

19. Sears MR, Taylor DR, Print CG. Regular inhaled b-agonist treatment in bronchial asthma. Lancet 1990;336:1391-6.

20. Piacentini GL, Peroni DG, Vicentini L, et al. Beta 2 agonists, exposure to allergens and bronchial hyperreactivity in childen with allergic asthma. Pediatr Med Chir 1995;17:515-7.

21. Drazen JF, Israel E, Boushey HA, et al. Comparison of regularly scheduled with as needed use of albuterol in mild asthma. N Engl J Med 1996;335:841-7.

22. Apter AJ, Reisine ST, Willard A, et al. The effect of inhaled albuterol in moderate to severe asthma. J Allergy Clin Immunol 1996;98:295-301.

\section{ReSUMO}

Objetivos: Avaliar o efeito protetor de diferentes doses de fenoterol $(F)$ inalado sobre a broncoconstrição induzida por metacolina (M). Tipo de Estudo: estudo duplo-cego e randomizado. Local: Centro de referência. Participantes: Nove crianças (7 a 15 anos) com asma leve ou moderada, alérgicas ao D. pteronyssinus. Intervenção: As doses de F (25 ou 50 ou 100 ou $200 \mathrm{mg}$ ) foram administradas por inalação com circuito fechado (De Vilbiss 646). No primeiro dia determinou-se a concentração de $M$ capaz de induzir queda de $20 \%$ nos valores de $\operatorname{VEF}_{1}\left(\mathrm{CP}_{20} \mathrm{VEF}_{1}\right)$. Nos dias subseqüentes, inalavam a dose de $\mathrm{F}$ pelo mesmo circuito medindo o VEF 15 minutos após (referência). A seguir iniciavam a broncoprovocação pela concentração anterior à da $\mathrm{CP}_{20} \mathrm{VEF}_{1}$ do primeiro dia e prosseguiam até que houvesse queda de $20 \%$ no valor do $\mathrm{VEF}_{1}$ para a determinação do novo $\mathrm{CP}_{20} \mathrm{VEF}_{1}$. Resultados: $\mathrm{O} \mathrm{F}$ inalado na dose de $25 \mathrm{mg}$ protegeu $2 / 9$ crianças e na de $50 \mathrm{mg}$ houve proteção de $4 / 9 \mathrm{crianças.}$ Todos os pacientes foram protegidos com as doses de 100 e $200 \mathrm{mg}$. Não observamos relação entre a magnitude da broncodilatação e broncoproteção induzidas pela inalação do F. Conclusões: Nossos resultados sugerem que a dose de 100 mg de $\mathrm{F}$ é protetora da broncoconstrição em crianças com asma leve/moderada. 